\title{
Wind relaxation and poleward flow events in the upwelling region off Baja California, Mexico
}

\section{Relajación del viento y flujos hacia el polo en la región de surgencias frente a Baja California, México}

\author{
Heriberto J Vazquez ${ }^{1,2 *}$, Jose Gomez-Valdes ${ }^{1}$ \\ ${ }^{1}$ Centro de Investigación Científica y de Educación Superior de Ensenada, Departamento de Oceanografía \\ Física. Carretera Tijuana-Ensenada, No. 3918, Zona Playitas, CP 28860, Ensenada, Baja California, Mexico. \\ 2 Scripps Institution of Oceanography, CASPO, Nierenberg Hall Room 425, La Jolla, San Diego, CA, 92093- \\ 0230, USA. \\ * Corresponding author. E-mail: hvazquezperalta@ucsd.edu
}

\begin{abstract}
Wind relaxation events are commonly observed in eastern boundary upwelling ecosystems. The wind fields over the southern part of the California Current System were separated into upwelling-favorable winds and wind relaxations by using a technique based on complex correlation analysis. Using vessel-mounted Acoustic Doppler Current Profiler and conductivity-temperature-depth observations from 4 consecutive Mexican Investigations of the California Current (IMECOCAL) cruises carried out during 2001-2002, a description of the ocean state associated with these stages of the wind field was elaborated for the northern Baja California (Mexico) upwelling region. Relaxation events occurred during each cruise. A coastal poleward flow event was conspicuous when a relaxation event followed a long upwelling favorable wind event. This pattern was also correlated with a negative or close to zero wind curl at the coast. A coastal equatorial jet and an upper-ocean offshore poleward flow were observed during spring, representing a typical upwelling pattern that is correlated with a large positive wind stress curl near the coast. In winter, a surface poleward flow was inhibited by a strong northwest wind event, which generated a shallow equatorward flow. The circulation patterns described here are consistent with theories that explain surface poleward flows through wind relaxation and negative wind curl.
\end{abstract}

Key words: winds, upwelling regions, poleward flows, wind relaxation events, IMECOCAL.

RESUMEN. Los eventos de relajación suelen observarse de manera común en los ecosistemas de surgencia de las corrientes limítrofes orientales. Los campos de viento sobre la región sur del Sistema de la Corriente de California fueron separados en vientos favorables para las surgencias y eventos de relajación por medio de una técnica basada en un análisis de correlación compleja. Se usaron los datos de un perfilador de corrientes Doppler montado en barco y las mediciones de conductividad, temperatura y profundidad de 4 cruceros consecutivos del programa Investigaciones Mexicanas de la Corriente de California (IMECOCAL) llevados a cabo entre 2001 y 2002 para describir el estado del océano con relación a esos tipos de viento en la región de surgencias de Baja California, México. Sucedieron eventos de relajación durante cada uno de los cruceros. Un flujo costero hacia el polo fue una característica persistente en el sistema cuando los eventos de relajación precedían a los eventos de vientos favorables para las surgencias de larga duración. Este flujo costero también estuvo correlacionado con un rotacional del esfuerzo del viento negativo o cercano a cero en la región costera. Un chorro costero hacia el ecuador y un flujo superficial fuera de la costa hacia el polo fueron observados en primavera, lo cual es un típico patrón de surgencias que esta correlacionado con un rotacional del esfuerzo del viento grande y positivo cerca de la costa. En invierno, un flujo superficial hacia el polo fue inhibido por fuertes vientos del noroeste, lo que generó un flujo superficial hacia el ecuador. Los patrones de circulación encontrados son consistentes con las teorías que explican los flujos superficiales hacia el polo a través de eventos de relajación y rotacional del viento negativo.

Palabras clave: vientos, regiones de surgencias, flujos hacia el polo, relajación del viento, IMECOCAL.

\section{INTRODUCTION}

Eastern boundary upwelling ecosystems have been a focus of attention in coastal oceanography due to their high primary productivity. Equatorward and poleward flows are commonly observed in these systems (Hill et al. 1998). Two different equatorward flows are regularly observed in eastern boundary upwelling ecosystems, one associated with the eastern limb of the anticyclonic subtropical gyre and the other with upwelling dynamics (Philander and Yoon 1982). Poleward flows have 2 signatures in the California Current System, a poleward

\section{INTRODUCCIÓN}

Los ecosistemas de surgencia de las corrientes limítrofes orientales han sido un foco de atención en la oceanografía regional debido a su alta productividad primaria. Los flujos hacia el ecuador y hacia el polo se observan comúnmente en estos sistemas (Hill et al. 1998). Dos tipos de flujos hacia el ecuador son observados regularmente en los ecosistemas de surgencia de las corrientes limítrofes orientales, uno asociado con el límite oriental del giro anticiclónico subtropical y el otro con la dinámica de las surgencias (Philander y Yoon 
California Undercurrent, confined to the continental slope, and a surface poleward current (i.e., Davidson Current) (Hickey 1979, Gay and Chereskin 2009). Durazo (2015) discussed the seasonality of the geostrophic signatures of the equatorward and poleward flows in the southern part of the California Current and found that the variability of the balanced flows was correlated with wind forcing.

In the eastern boundary upwelling ecosystems, surface poleward currents are regularly associated with wind relaxation; for example, Relvas and Barton (2002), using satellite imagery and observations over the coast of the Iberian Peninsula, found a relationship between winds and the coastal countercurrent. The same relation was found by Garel et al. (2016) for the inner shelf of the Gulf of Cadiz by using a multiyear time series of Acoustic Doppler Current Profiler (ADCP) observations and relating it to winds from different sources. Winant et al. (2003) reported several circulation patterns at the boundary between the central and southern California coasts, showing that when upwelling-favorable winds cease or relax a poleward flow develops. Melton et al. (2009), using wind time series from buoys, identified wind relaxation events over central California waters and associated them with warm poleward currents. Torres and GomezValdes (2015) also found that poleward flow events follow wind relaxation events off the northern Baja California coast.

In the southern part of the California Current System, winds predominantly blow from the northwest (equatorward and parallel to the coast) throughout the year (Bakun and Nelson 1991). This pattern is even observed in average fields over a short period of time (days) or in climatologies as the ones shown in Soto-Mardones et al. (2004). The aim of this study is to evidence from vessel-mounted ADCP data that poleward flow events follow wind relaxation events in the northern Baja California upwelling region. In addition, the upwelling pattern is discussed. A new technique for the separation of the wind field into upwelling-favorable winds and relaxation events is introduced. Ocean wind observations obtained from satellite remote sensors and shipboard observations from 4 Mexican Investigations of the California Current (IMECOCAL, for its acronym in Spanish) cruises with a vessel-mounted $\mathrm{ADCP}$ and a conductivity-temperature-depth (CTD) profiler are used to describe ocean dynamics off the northern Baja California coast.

\section{MATERIALS AND METHODS}

Cross-Calibrated Multi-Platform (CCMP) and QuikSCAT ocean wind observations, processed by the Physical Oceanography Distributed Active Archive Center (PO.DAAC) and by the NOAA National Environmental Satellite, Data, and Information Service (NESDIS), respectively, were analyzed. Wind observations lasted from 1 September 2001 to 31 October 2002. Wind over the study area is mainly upwelling-favorable (coherent in direction). A wind relaxation event occurs when the regular and coherent wind loses
1982). Se pueden identificar 2 tipos de flujos hacia el polo en el Sistema de la Corriente de California, la corriente subsuperficial, que esta confinada en la plataforma continental, y la corriente superficial (i.e., corriente de Davidson) (Hickey 1979, Gay y Chereskin 2009). Durazo (2015) discutió la señal estacional de la señal geostrófica de los flujos hacia el ecuador y hacia el polo en la región sur de la corriente de California y encontró que la variabilidad de los flujos geostróficos está correlacionada con el forzamiento del viento.

Las corrientes superficiales hacia el polo en los ecosistemas de surgencia de las corrientes limítrofes orientales se relacionan comúnmente con la relajación del viento; por ejemplo, Relvas y Barton (2002), con base en imágenes de satélite y observaciones sobre la costa de la península ibérica, encontraron una relación entre los vientos y la contracorriente costera. La misma relación fue encontrada por Garel et al. (2016) en la plataforma continental interior del golfo de Cádiz. Ellos usaron una serie de tiempo multianual de observaciones de un Perfilador de Corrientes Acústico Doppler (ADCP) y la relacionaron con vientos de diferentes bases de datos. Winant et al. (2003) reportaron varios patrones de circulación en la frontera entre la parte central y la parte sur de la costa de California, y mostraron que cuando los vientos favorables para las surgencias cesan o se relajan, se desarrolla un flujo hacia el polo. Melton et al. (2009), con base en series de tiempo de vientos medidos por anemómetros en boyas, identificaron eventos de relajación sobre las aguas frente a la parte central de California y los asociaron con corrientes cálidas hacia el polo. Torres y Gomez-Valdes (2015) también encontraron que los flujos hacia el polo ocurren después de eventos de relajación frente a la costa de Baja California.

En la parte sur del Sistema de la Corriente de California, los vientos provienen predominantemente del noroeste (hacia el ecuador y paralelos a la costa) durante todo el año (Bakun y Nelson 1991). Este patrón es recurrente inclusive en campos promedio realizados sobre periodos cortos de tiempo (días) o en climatologías como las mostradas en Soto-Mardones et al. (2004). El objetivo de este estudio es reportar evidencias, con datos de un ADCP montado en barco, de que después de los eventos de relajación del viento, ocurren flujos hacia el polo en la zona de surgencias frente a la región norte de la península de Baja California. Además, se discute el patrón de surgencias. Se introduce una nueva técnica para la separación del campo de viento en vientos favorables para las surgencias y eventos de relajación. Se usan observaciones de vientos oceánicos obtenidas de sensores satelitales y datos del ADCP montado en barco y de conductividad, temperatura, y profundidad (CTD) obtenidos de 4 cruceros del programa Investigaciones Mexicanas de la Corriente de California (IMECOCAL) para describir la dinámica del océano frente a la costa norte de la península de Baja California.

\section{MATERIALES Y MÉTODOS}

Se analizaron observaciones de vientos oceánicos del proyecto Cross-Calibrated Multi-Platform (CCMP) y de 
intensity and coherence. This event is identified by a point-topoint comparison between the time-averaged field (14 months of 6-hourly data) and the instantaneous fields (6-hourly data). One reasonable way of doing so is by finding the $\alpha$ value that establishes the best relation, in a least-squares sense, between the time-averaged field and the instantaneous field. Because we were dealing with vector quantities, we were able to use a complex representation of the data. Let $\overline{\boldsymbol{\tau}}$ be the vectorized (one column) representation of the time-averaged field and $\boldsymbol{\tau}_{k}$ be the $k$ th vectorized (one column) representation of the 6-h field, where each of the elements in $\tau$ is a complex number with real and imaginary parts corresponding to the east and north components of the wind stress, respectively. So, we can write as follows:

$$
\boldsymbol{\tau}_{k}-\bar{\tau} \alpha_{k}=\boldsymbol{e}_{k}
$$

where $\boldsymbol{e}_{k}$ is the vector difference between the instantaneous field and the estimation. Solving for $\alpha_{k}$ (each time) by minimizing the summation of the square of the magnitude of the vector difference between instantaneous and time-averaged fields $\left(\boldsymbol{e}_{k}^{H} \boldsymbol{e}_{k}\right)$ leads to:

$$
\alpha_{k}=\frac{\overline{\boldsymbol{\tau}}^{H} \boldsymbol{\tau}_{k}}{\overline{\boldsymbol{\tau}}^{H} \overline{\boldsymbol{\tau}}},
$$

where $H$ stands for the Hermitian or conjugate transpose, since the elements in the vectors are complex numbers. The numerator is a complex number and the denominator is a real number; therefore, $\alpha$ is a complex number whose magnitude stretches or squeezes, and its phase rotates the vectors in field $\overline{\boldsymbol{\tau}}$. Note the similarity with the concept of gain used in the spectral analysis that defines the ratio between spectra from 2 time series (Bendat and Piersol 2010). In order to identify the relaxation events, the coefficient of determination $\left(r_{k}^{2}\right)$ was calculated. This coefficient is an estimation of the variance explained by the fitting. In this case it is represented by the following equation:

$$
r_{k}^{2}=\frac{\left(\boldsymbol{\tau}_{k}^{H} \overline{\boldsymbol{\tau}}\right)\left(\boldsymbol{\tau}_{k}^{H} \overline{\boldsymbol{\tau}}\right)}{\left(\boldsymbol{\tau}_{k}^{H} \boldsymbol{\tau}_{k}\right)\left(\overline{\boldsymbol{\tau}}^{H} \overline{\boldsymbol{\tau}}\right)},
$$

which is the square of the complex correlation coefficient described by Kundu (1976), who used it to estimate Ekman veering between 2 vector time series. Briefly, wind relaxation events were determined by the values of the complex correlation ( $r$ ) analysis between the 14-month (from September 2001 to October 2002) average wind field and the 6-h wind fields. Relaxation events were found as follows. First, we computed the probability distribution of the complex correlation values. Second, we obtained the average with $95 \%$ confidence interval (the probability distribution was exponential). We defined relaxation events as the values of the correlation coefficients outside that interval. Low correlation values are indicators of incoherent winds, which are defined as relaxation events. Although both datasets were used (QuikSCAT
QuikSCAT, las cuales fueron procesadas por el Centro de Archivos Activos de Distribución de Oceanografía Física (PO.DAAC, por sus siglas en inglés) y por el Servicio Nacional de Satélites Ambientales, Datos e Información (NESDIS, por sus siglas en inglés) de la NOAA, respectivamente. Las observaciones del viento abarcaron desde el primero de septiembre de 2001 hasta el 31 de octubre de 2002. El viento sobre el área de estudio es principalmente favorable para las surgencias (tiene una dirección coherente). Los eventos de relajación ocurren cuando hay una pérdida de intensidad y coherencia en el viento típico. Estos eventos se identifican comparando punto a punto el campo del viento promediado en el tiempo (14 meses de datos cada $6 \mathrm{~h}$ ) con los campos instantáneos (cada 6 h). Una manera razonable de hacer esto es encontrando el valor $\alpha$ que establece la mejor relación, en el sentido de mínimos cuadrados, entre el campo promedio y el campo instantáneo. Debido a que nosotros utilizamos cantidades vectoriales, pudimos utilizar la representación compleja de los datos. Sea $\overline{\boldsymbol{\tau}}$ la representación vectorizada (una columna) del campo promedio y $\boldsymbol{\tau}_{k}$ la $k$-ésima representación vectorizada (una columna) del campo instantáneo, donde cada uno de los elementos en $\boldsymbol{\tau}$ es un número complejo con la parte real e imaginaria correspondientes a las componentes este y norte del esfuerzo del viento, respectivamente, de manera que podemos escribir la ecuación que sigue:

$$
\boldsymbol{\tau}_{k}-\overline{\boldsymbol{\tau}} \alpha_{k}=\boldsymbol{e}_{k}
$$

donde $\boldsymbol{e}_{k}$ es la diferencia vectorial entre el campo instantáneo y la estimación. Al resolver $\alpha_{k}$ (cada tiempo) por medio de la minimización de la sumatoria del cuadrado de la magnitud de la diferencia de vectores entre el campo instantáneo y el campo promedio $\left(\boldsymbol{e}_{k}^{H} \boldsymbol{e}_{k}\right)$, se tiene lo siguiente:

$$
\alpha_{k}=\frac{\overline{\boldsymbol{\tau}}^{H} \boldsymbol{\tau}_{k}}{\overline{\boldsymbol{\tau}}^{H} \overline{\boldsymbol{\tau}}}
$$

donde $H$ es el transpuesto conjugado, ya que los elementos en el vector son números complejos. El numerador es un número complejo y el denominador es un número real; por tanto, $\alpha$ será un número complejo cuya magnitud incrementa o decrece, y su fase rota los vectores en el campo $\overline{\boldsymbol{\tau}}$. Nótese la similitud con el concepto de admitancia utilizado en el análisis espectral que define la razón entre los espectros de 2 series temporales (Bendat y Piersol 2010). Para identificar los eventos de relajación, calculamos el coeficiente de determinación $\left(r_{k}^{2}\right)$. Este coeficiente es una estimación de la varianza explicada por el ajuste. En nuestro caso, estuvo representado por la siguiente ecuación:

$$
r_{k}^{2}=\frac{\left(\boldsymbol{\tau}_{k}^{H} \overline{\boldsymbol{\tau}}\right)\left(\boldsymbol{\tau}_{k}^{H} \overline{\boldsymbol{\tau}}\right)}{\left(\boldsymbol{\tau}_{k}^{H} \boldsymbol{\tau}_{k}\right)\left(\overline{\boldsymbol{\tau}}^{H} \overline{\boldsymbol{\tau}}\right)}
$$

la cual es el cuadrado del coeficiente de correlación compleja descrito por Kundu (1976), quien lo usó para estimar la diferencia en dirección debida a Ekman entre 2 series de tiempo 
and CCMP), only CCMP results are shown because of their better resolution.

The results obtained from the complex correlation technique were validated using 2 independent methods. The method to identify wind relaxation events described in Melton et al. (2009) was implemented first. This method is based on an empirical orthogonal function (EOF) analysis of the wind field. Once the mode that captures the upwelling pattern is found, the wind relaxation event is identified by the reversing in the sign of the principal component (PC) time series. An EOF analysis of the wind stress curl was used as a second validation method. The wind stress curl has a distinctive pattern in the California Current region: it is negative offshore and positive near the coast (Winant and Dorman 1997). Moreover, Ekman pumping (wind stress curl) in the region is as important as Ekman transport (wind stress) for upwelling intensification (Enriquez and Friehe 1995). Therefore, wind can be characterized by performing an EOF decomposition of the wind stress curl and by identifying the mode that is negative offshore and positive near the coast. Computation of EOFs was carried out following Emery and Thomson (1998).

ADCP and CTD observations were used to describe ocean circulation. ADCP observations provide both the balanced and the unbalanced flows (Rossby et al. 2011). The observations were taken by the IMECOCAL program, which is an ongoing observational effort that started in autumn 1997, with continuous quarterly surveys carried out in the southern portion of the California Current (off Baja California) aboard the R/V Francisco de Ulloa and the R/V Alpha Helix. The observations used for this work were taken using the former $\mathrm{R} / \mathrm{V}$, which carried a hull-mounted RDI broadband ADCP $(153.6 \mathrm{kHz})$ at approximately $2.8 \mathrm{~m}$ beneath the sea surface and a Sea-Bird CTD instrument that was used on a regular basis. The IMECOCAL sampling grid is a reduced CalCOFI (California Cooperative Oceanic Fisheries Investigations) sampling grid off the Baja California Peninsula. A description of the CalCOFI sampling scheme can be found in Lynn and Simpson (1987). The ADCP data were processed and detided according to Vazquez et al. (2011) and the CTD data according to Gomez-Valdes and Jeronimo (2009). Objective mapping (optimum interpolation) was used to estimate the velocity fields from the ADCP data and the dynamic height anomaly from the CTD data using the approach of Jeronimo and Gomez-Valdes (2007). In this work, 4 consecutive IMECOCAL surveys, namely 4-10 October 2001, 19-28 January 2002, 21-27 April 2002, and 12-19 July 2002 , were used to describe a typical year with relaxation events and the associated circulation pattern off northern Baja California.

\section{RESULTS}

The wind relaxation events identified with the magnitude of the complex correlation coefficients $\left(\left|r_{k}\right|\right)$ are shown vectoriales. En concreto, los eventos de relajación del viento fueron determinados por los valores de correlación compleja (r) entre el campo de viento promedio de 14 meses de datos (de septiembre de 2001 a octubre de 2002) y los campos de viento de cada $6 \mathrm{~h}$. Los eventos de relajación fueron definidos de la siguiente manera. Primero, calculamos la distribución de probabilidad de los valores de correlación compleja. Después, obtuvimos la media con un intervalo de confianza del $95 \%$ (la distribución de probabilidad fue exponencial). Definimos los eventos de relajación como los valores de correlación que estuvieran fuera de este intervalo. Las correlaciones bajas indican vientos incoherentes, los cuales son definidos como eventos de relajación. Aunque ambos conjuntos de datos fueron utilizados (QuikSCAT y CCMP), únicamente se presentan los resultados de CCMP debido a que su resolución es mejor.

Los resultados obtenidos con el método de correlación compleja fueron validados usando 2 métodos independientes. Se implementó primero el método para identificar eventos de relajación del viento descrito por Melton et al. (2009). Este método se basa en un análisis de funciones empíricas ortogonales (FEO) aplicado al campo de viento. Se tienen que identificar tanto el modo que captura el patrón de surgencias en el espacio como el signo correspondiente de la serie temporal de la componente principal (CP); los eventos de relajación son aquellos en los cuales la serie temporal de la CP cambia de signo con respecto al patrón identificado de surgencias. El segundo método de validación se basa en un análisis de FEO del rotacional del esfuerzo del viento. El rotacional del esfuerzo del viento tiene un patrón distintivo en la región de la corriente de California: es negativo fuera de la costa y positivo cerca de la costa (Winant y Dorman 1997). Además, el bombeo de Ekman (rotacional del esfuerzo del viento) influye tanto como el transporte de Ekman (esfuerzo del viento) en la intensidad de las surgencias en la región (Enriquez y Friehe 1995). Por lo tanto, se puede caracterizar el viento mediante la descomposición en FEO del rotacional del esfuerzo del viento y la identificación del modo que es negativo fuera de la costa y positivo cerca de la costa. Los cálculos de las FEO se realizaron siguiendo el proceso descrito por Emery y Thompson (1998).

La circulación del océano se describió utilizando las observaciones del ADCP y de CTD. Las observaciones del ADCP proporcionan la velocidad total del océano, es decir, están conformadas por flujos geostróficos y no geostróficos (Rossby et al. 2011). El programa IMECOCAL, que es un programa observacional que inició en otoño de 1997 y continúa llevando a cabo cruceros oceanográficos trimestrales cada año en la región sur de la corriente de California (en las aguas frente a la península de Baja California), fue el encargado de recolectar los datos usando los buques oceanográficos Francisco de Ulloa y Alpha Helix. Las observaciones usadas en este trabajo fueron tomadas por el primer buque oceanográfico, el cual llevaba un ADCP RDI de banda ancha de $153.6 \mathrm{kHz}$ montado en el casco a una profundidad aproximada 
in Figure 1a. The spatial and temporal patterns for the first EOF of the wind stress curl account for $19 \%$ of the total variance (Fig. 1b, c). The separation of the coastal zone from the open-ocean zone in the spatial pattern is noteworthy. The PC time series irregularly switched from positive to negative anomalies and was highly correlated with the total kinetic energy of the wind over the region, which means that low kinetic energy corresponds to low or negative wind stress curl over the coast. In general, wind relaxation events were correlated with coastal near-zero or negative anomalies (low kinetic energy values), while coherent winds were correlated with coastal positive anomalies. These results confirm the reliability of our method. Each of the 4 surveys showed at least one relaxation event. In October 2001 a wind relaxation event occurred at the beginning of the cruise. Before the January 2002 cruise, a relaxation event took place, changing to coherent wind (correlation coefficient $\sim 1$ ) at the beginning of the cruise but changing back to a relaxation event a couple of days after the survey started. In the April 2002 cruise, winds were coherent until about halfway through the survey; afterwards, a short wind relaxation event took place. In the July 2002 cruise, 2 relaxation events occurred, one at the beginning and the other after the ship had moved halfway down its pathway.

The method described by Melton et al. (2009) was the first attempt to implement an objective method for the identification of wind relaxation events. The agreement between the results obtained with the Melton et al. (2009) method and our method is a remarkable result. The method described here, based on complex correlation, identified wind relaxation periods that corresponded to a sign reversal of the PC time series with a simple analysis (Fig. 2).

The horizontal circulation during the October 2001 cruise was dominated by 2 mesoscale eddies, one cyclonic and the other anticyclonic, both of approximately $160 \mathrm{~km}$ in diameter (Fig. 3). A coastal poleward flow between $29.5^{\circ} \mathrm{N}$ and $31.5^{\circ} \mathrm{N}$, which was unrelated to the offshore cyclonic circulation at the same latitudes, was observed. The horizontal circulation during the January 2002 cruise was dominated by an anticyclonic eddy, centered at $28.7^{\circ} \mathrm{N}$ and $116.5^{\circ} \mathrm{W}$, with a diameter of $\sim 160 \mathrm{~km}$. The eddy was visible in the dynamic height field derived from CTD data and in the vector field derived from ADCP data; in addition, 2 more low-pressure disturbances were present in the dynamic height field. Circulation during the April 2002 cruise was dominated by an apparent meandered equatorward flow, which could have been a product of the relaxed state of the wind that occurred between the middle and the end of the cruise (Fig. 1a). Finally, the horizontal circulation in the July 2002 cruise was dominated by a cyclonic eddy, centered at $31.25^{\circ} \mathrm{N}$ and $117.5^{\circ} \mathrm{W}$, with a diameter of $\sim 140 \mathrm{~km}$ and 2 high-pressure structures at the boundary of the domain.

The analysis was extended to the vertical along the line marked in Figure 3. This line was chosen because wind relaxation events occurred when the ship was navigating de $2.8 \mathrm{~m}$ y un CTD Sea-Bird con el cual se realizaron lances de manera regular. La malla de muestreo de IMECOCAL es una versión reducida de la malla de muestreo de CalCOFI (California Cooperative Oceanic Fisheries Investigations) y abarca la región frente a la península de Baja California. Una descripción de la malla de muestreo utilizada por el programa CalCOFI se encuentra en Lynn y Simpson (1987). Los datos del ADCP fueron procesados y corregidos para eliminar el efecto de la marea siguiendo lo descrito por Vazquez et al. (2011), y los datos de CTD fueron procesados como se indica en Gomez-Valdes y Jeronimo (2009). Se usó interpolación objetiva para estimar los campos de velocidades a partir de los datos del ADCP y de la anomalía de altura dinámica obtenida de los datos de CTD siguiendo la técnica de Jeronimo y Gomez-Valdes (2007). En este trabajo se utilizaron datos de 4 muestreos consecutivos de IMECOCAL para describir un año típico con eventos de relajación y los patrones de circulación asociados a ellos frente a la región norte de la península de Baja California. Los cruceros utilizados se realizaron en los periodos de tiempo del 4 al 10 de octubre de 2001, del 19 al 28 de enero de 2002, del 21 al 27 de abril de 2002 y del 12 al 19 de julio de 2002 .

\section{Resultados}

Los eventos de relajación del viento identificados por medio de la magnitud del coeficiente de correlación compleja $\left(\left|r_{k}\right|\right)$ se muestran en la Figura 1a. El patrón espacial y temporal para la primer FEO del rotacional del esfuerzo del viento explicó el 19\% de la varianza total (Fig. 1b, c). La separación de la zona costera y la zona oceánica es evidente en el patrón espacial. La serie de tiempo de la CP cambió irregularmente de anomalías positivas a negativas y estuvo altamente correlacionada con la energía cinética total del viento sobre la región, lo que significa que una energía cinética baja se corresponde con un rotacional del esfuerzo del viento bajo o negativo en la región costera. En general, los eventos de relajación del viento se correlacionaron con anomalías costeras cercanas a cero o negativas (valores de energía cinética bajos), mientras que los vientos coherentes se correlacionaron con anomalías positivas cercanas a la costa. Estos resultados confirman la fiabilidad de nuestro método. En cada uno de los 4 cruceros se registró al menos un evento de relajación. En octubre 2001 un evento de relajación del viento ocurrió al inicio del crucero. Antes del crucero de enero de 2002 ocurrió un evento de relajación del viento que cambió a un evento de viento coherente (coeficiente de correlación cercano a 1) al inicio del crucero, pero cambió de nuevo a un evento de relajación un par de días después. Durante el crucero de abril de 2002, los vientos fueron coherentes aproximadamente hasta medio crucero; después, ocurrió un evento de relajación. Durante el crucero de julio de 2002, ocurrieron 2 eventos de relajación, uno al principio y el otro después de la mitad del crucero.

El método descrito por Melton et al. (2009) fue el primer intento para implementar un método objetivo para la 
along this line in 3 out of 4 surveys. We were therefore able to compare the effect of a relaxation event in the vertical at different times and at the same location, as well as comparing the patterns when coherent winds were present (April 2002). Figures 4 and 5 show the vertical cross section along the line for the velocity component parallel to the coast and for temperature, respectively, during each cruise. In October, a coastal poleward flow was observed penetrating down to $124 \mathrm{~m}$ deep, with an average speed of about $0.38 \mathrm{~m} \cdot \mathrm{s}^{-1}$ and weak vertical shear (i.e., barotropic-like). An anticyclonic circulation occurred offshore. In January 2002 there were weak flows with strong vertical shear (i.e., baroclinic). A coastal poleward flow was centered at $50 \mathrm{~m}$ deep, with an average identificación de eventos de relajación. La similitud entre los resultados del método de Melton et al. (2009) y de nuestro método es alta. El método de correlación compleja descrito aquí identifica eventos de relajación que se corresponden con periodos en los cuales hubo un cambio de signo en la serie de tiempo de la CP con un análisis simple (Fig. 2).

La circulación horizontal durante el crucero de octubre de 2001 estuvo dominada por 2 remolinos de mesoescala, uno ciclónico y el otro anticiclónico, ambos con un diámetro aproximado de $160 \mathrm{~km}$ (Fig. 3). Se observó un flujo costero hacia el polo entre $29.5^{\circ} \mathrm{N}$ y $31.5^{\circ} \mathrm{N}$, el cual estaba desconectado del giro ciclónico fuera de la costa a las mismas latitudes. La circulación horizontal durante el crucero de enero de 2002
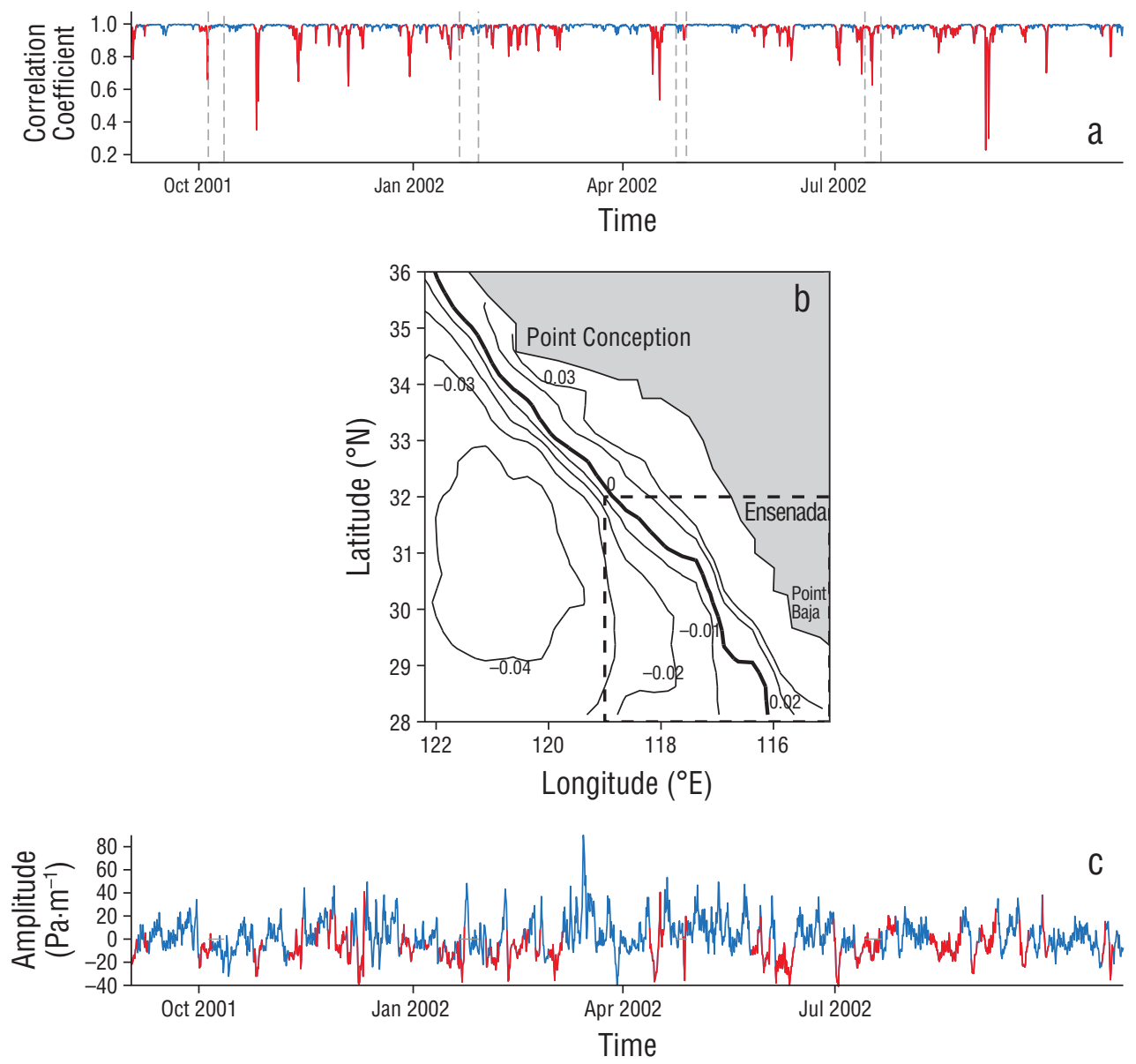

Figure 1. (a) Magnitude of the complex correlation; wind relaxation events are marked with red lines and coherent winds with blue lines. (b) Spatial pattern of the first empirical orthogonal function mode of the wind stress curl and (c) its corresponding principal component time series. The time intervals within which relaxation events occurred are marked in red in the principal component time series. Gray dashed lines in (a) indicate the time periods for the cruises. In (b) isolines indicate the spatial distribution of the first mode (thick line is zero) and the dashed square encompasses the study area.

Figura 1. (a) Magnitud de la correlación compleja; los eventos de relajación del viento están marcados con líneas rojas y el viento coherente con líneas azules. (b) Patrón espacial del primer modo de la función empírica ortogonal del rotacional del esfuerzo del viento y (c) la serie temporal de la componente principal correspondiente. Los intervalos en los que ocurrieron los eventos de relajación están marcados en rojo sobre la serie temporal de la componente principal. Las líneas discontinuas grises en (a) indican los periodos de los cruceros. En (b) las isolíneas indican la distribución espacial del primer modo (la línea gruesa es cero), y el recuadro con línea discontinua enmarca la región de estudio. 
velocity of $0.10 \mathrm{~m} \cdot \mathrm{s}^{-1}$, and a shallow equatorward flow was observed in the surface layer. In April, there were 2 branches of equatorward flow, and a poleward flow developed offshore. A coastal baroclinic equatorward jet $\left(\sim 0.40 \mathrm{~m} \cdot \mathrm{s}^{-1}\right)$ was confined to the upper $100 \mathrm{~m}$ of the water column. The core of the open-ocean poleward flow was also confined to the upper ocean. The second branch of the equatorward flow was barotropic-like and occurred offshore, beyond $45 \mathrm{~km}$ from the coast, with an average speed of about $0.35 \mathrm{~m} \cdot \mathrm{s}^{-1}$. The velocity pattern in July was associated with a cyclonic circulation with nearshore poleward flow and offshore equatorward flow. However, the coastal baroclinic poleward flow seemed to be disconnected from the dominant cyclonic circulation further offshore. The disconnection was evident after analyzing the velocity and temperature profiles simultaneously. The poleward flow had its core at $100 \mathrm{~m}$ deep and a speed of about $0.30 \mathrm{~m} \cdot \mathrm{s}^{-1}$.

In October a core of warm water with an average temperature of $19^{\circ} \mathrm{C}$ was observed offshore, which is in agreement with the structure of the anticyclonic eddy (Fig. 5). In January warm water was observed in the mixed layer, which was $\sim 60 \mathrm{~m}$ deep. There was a low-temperature band

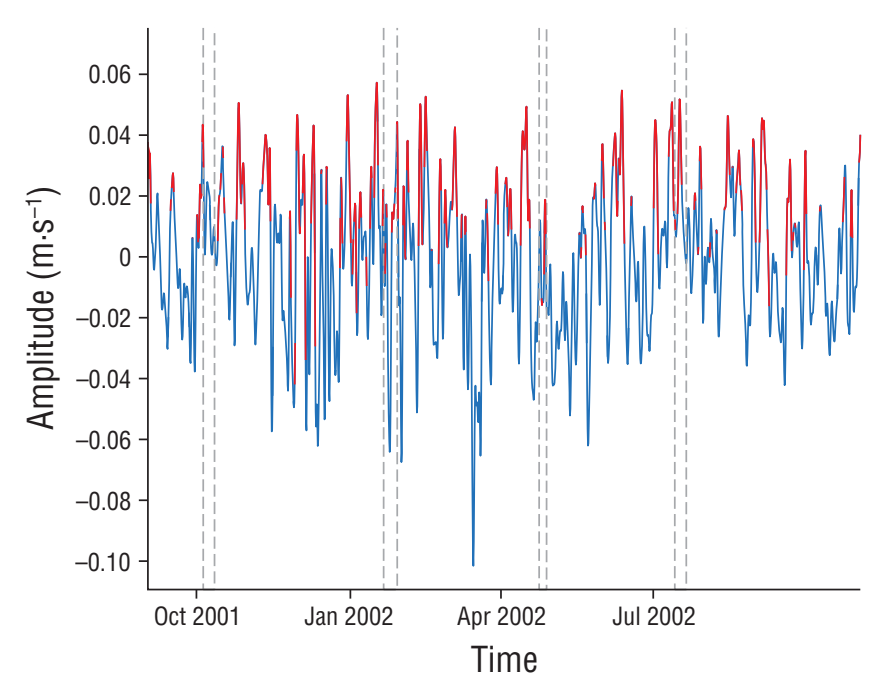

Figure 2. Principal component time series of the first mode that represents the upwelling relaxation pattern (following Melton et al. 2009). Negative values correspond to upwelling-favorable winds and positive values to relaxation events. Marked in red are the time intervals in which the complex correlation technique identified relaxation events. Gray dashed lines indicate the periods for the cruises

Figura 2. Serie de tiempo de la componente principal del primer modo que representa el patrón de relajación de surgencias (de acuerdo con Melton et al. 2009). Los valores negativos corresponden a los vientos favorables para las surgencias y los valores positivos corresponded a los eventos de relajación. Se marcan en rojo los intervalos de tiempo de los eventos de relajación identificados por la técnica de correlación compleja. Las líneas discontinuas grises indican los periodos de los cruceros. estuvo dominada por un remolino anticiclónico centrado en $28.7^{\circ} \mathrm{N}$ y $116.5^{\circ} \mathrm{W}$, con un diámetro aproximado de $160 \mathrm{~km}$. El remolino fue visible en el campo de la altura dinámica derivada de los datos de CTD y en el campo vectorial obtenido con los datos del ADCP. Además, otras 2 estructuras de baja presión estuvieron presentes en el campo de altura dinámica. La circulación durante el crucero de abril de 2002 estuvo dominada por un aparente meandro fluyendo hacia el ecuador, el cual pudo haber sido producto de la relajación del viento que ocurrió entre mediados y finales del crucero (Fig. 1a). Finalmente, la circulación horizontal durante el crucero de julio de 2002 estuvo dominada por un remolino ciclónico centrado en $31.25^{\circ} \mathrm{N}$ y $117.5^{\circ} \mathrm{W}$, con un diámetro de aproximadamente $140 \mathrm{~km}$ y 2 estructuras de alta presión en la frontera del dominio.

El análisis se extendió a la vertical a lo largo de la línea marcada en la Figura 3. Se seleccionó esta línea debido a que ocurrieron eventos de relajación cuando el barco estaba navegando esta línea en 3 de los 4 cruceros. De esta manera, se pudo comparar el efecto de los eventos de relajación en la vertical en diferentes tiempos y en la misma región, además de observar el patrón del evento de viento coherente cuando este se presentó (abril 2002). Las Figuras 4 y 5 muestran, para cada uno de los cruceros, la sección vertical de la componente de velocidad paralela a la costa y de la temperatura, respectivamente, a lo largo de la línea antes mencionada. En octubre, fue evidente la presencia de un flujo costero hacia el polo, con estructura vertical débil (i.e., del tipo barotrópico), que se ubicó desde la superficie hasta $124 \mathrm{~m}$ de profundidad y presentó una velocidad media de $0.38 \mathrm{~m} \cdot \mathrm{s}^{-1}$. Se observó un flujo anticiclónico mar adentro. En enero de 2002 hubo flujos débiles con una estructura vertical fuerte (i.e., baroclínicos). Un flujo costero dirigido hacia el polo estaba centrado a $50 \mathrm{~m}$ de profundidad, con una velocidad media de $0.10 \mathrm{~m} \cdot \mathrm{s}^{-1}, \mathrm{y}$ se observó un flujo superficial hacia el ecuador. En abril se observaron 2 señales de flujos hacia el ecuador, mientras que fuera de la costa se desarrolló un flujo hacia el polo. Uno de los flujos hacia el ecuador era un chorro baroclínico cerca de la costa $\left(\sim 0.40 \mathrm{~m} \cdot \mathrm{s}^{-1}\right)$ confinado a los primeros $100 \mathrm{~m}$ de la columna de agua. El otro flujo hacia el ecuador fue principalmente barotrópico y ocurrió a más de $45 \mathrm{~km}$ de la costa, con una velocidad media de $0.35 \mathrm{~m} \cdot \mathrm{s}^{-1}$. El núcleo del flujo oceánico hacia el polo también estuvo confinado a la parte superficial del océano. El perfil de velocidad en julio mostró una circulación ciclónica con flujo hacia el polo cerca de la costa y flujo hacia el ecuador fuera de la costa. Sin embargo, el flujo baroclínico costero hacia el polo parecía estar desconectado de la circulación ciclónica dominante fuera de la costa. La desconexión fue evidente cuando se analizaron los perfiles de velocidad y temperatura de manera simultánea. El núcleo del flujo hacia el polo se ubicó a $100 \mathrm{~m}$ de profundidad y presentó una velocidad de alrededor de $0.30 \mathrm{~m} \cdot \mathrm{s}^{-1}$.

En octubre, se observó un núcleo de agua cálida fuera de la costa con una temperatura media de $19{ }^{\circ} \mathrm{C}$, lo cual concuerda con la estructura anticiclónica (Fig. 5). En enero se observó 
$\left(10.0-12.5^{\circ} \mathrm{C}\right)$ close to the coast in April, as a result of strong upwelling. In July 2 cores of warm water were established and separated by the center of the cyclonic circulation.

\section{Discussion}

A new method to identify wind relaxation events in two-dimensional wind fields has been introduced. The basis of this method is the complex correlation that measures the square root of the variance explained by a simple complex regression between the average wind stress field and the instantaneous $(6 \mathrm{~h})$ field. The method is also useful in identifying intervals of coherent winds, which are associated with upwelling-favorable winds. Our implementation allowed the identification of 45 relaxation events during the period from September 2001 to October 2002, most of which were separated by periods of coherent winds. A long period of coherent winds occurred during April 2002. Because the method is based on intensity and on how well the instantaneous field resembles the average field, it is insensitive to the choice of dataset. The relationship between the wind relaxation plot and the first PC of the wind stress curl is noteworthy; we found that wind stress curl variability is controlled by agua cálida dentro de la capa de mezcla, la cual fue de aproximadamente $60 \mathrm{~m}$. Hubo una franja de baja temperatura $\left(10-12.5^{\circ} \mathrm{C}\right)$ cerca de la costa en abril, la cual se debió a una surgencia intensa. En julio se observaron 2 núcleos de agua cálida separados por el centro de la circulación ciclónica.

\section{Discusión}

Se introdujo un nuevo método para identificar eventos de relajación en campos de viento bidimensionales. El método se basa en la correlación compleja, que no es más que la raíz cuadrada de la varianza explicada por una simple regresión lineal compleja entre el campo del esfuerzo de viento promedio en la zona y los campos instantáneos $(6$ h). El método también es útil para identificar intervalos de vientos coherentes, los cuales se relacionan con vientos favorables para las surgencias. Nuestra implementación nos permitió identificar 45 eventos de relajación durante el periodo de septiembre de 2001 a octubre de 2002, la mayoría de ellos separados por periodos de vientos coherentes. Durante abril de 2002 se presentó un largo periodo de vientos coherentes. Debido a que el método se basa en la intensidad y en qué tanto se asemeja el campo instantáneo al campo promedio,

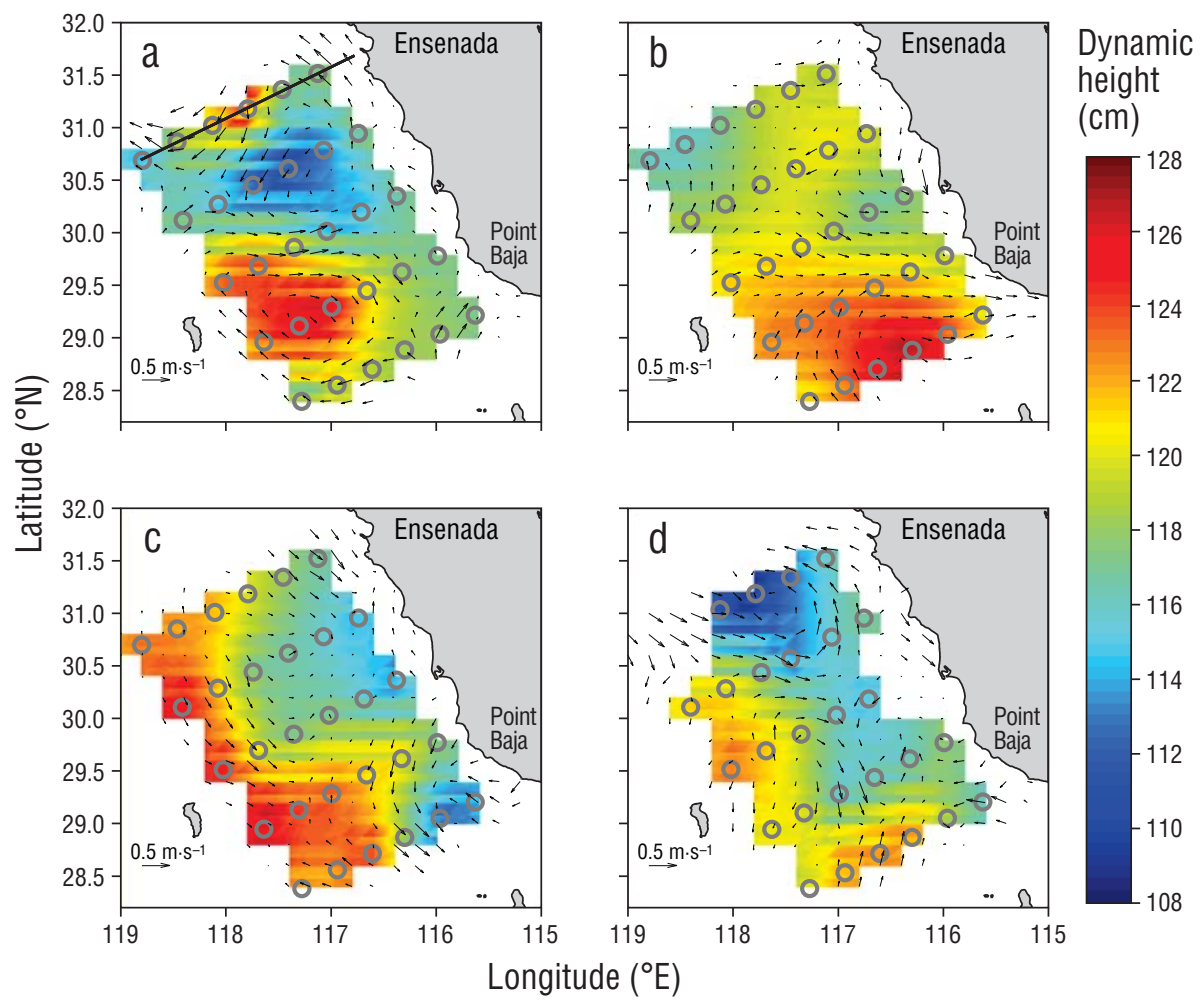

Figure 3. Distribution of ADCP velocity at $60 \mathrm{~m}$ (arrows) and of dynamic height at 60/1,000 dbar (color scale) in October 2001 (a), January 2002 (b), April 2002 (c), and July 2002 (d). The solid line marks a cross section off Ensenada. The gray circles indicate the CTD casts that reached at least $1,000 \mathrm{~m}$ deep.

Figura 3. Distribución de la velocidad del ADCP a $60 \mathrm{~m}$ (flechas) y de la altura dinámica a 60/1,000 dbar (escala de color) en octubre de 2001 (a), enero de 2002 (b), abril de 2002 (c) y julio de 2002 (d). La línea continua marca un corte transversal frente a Ensenada. Los círculos grises indican los lances de CTD que alcanzaron un mínimo de 1,000 $\mathrm{m}$ de profundidad. 


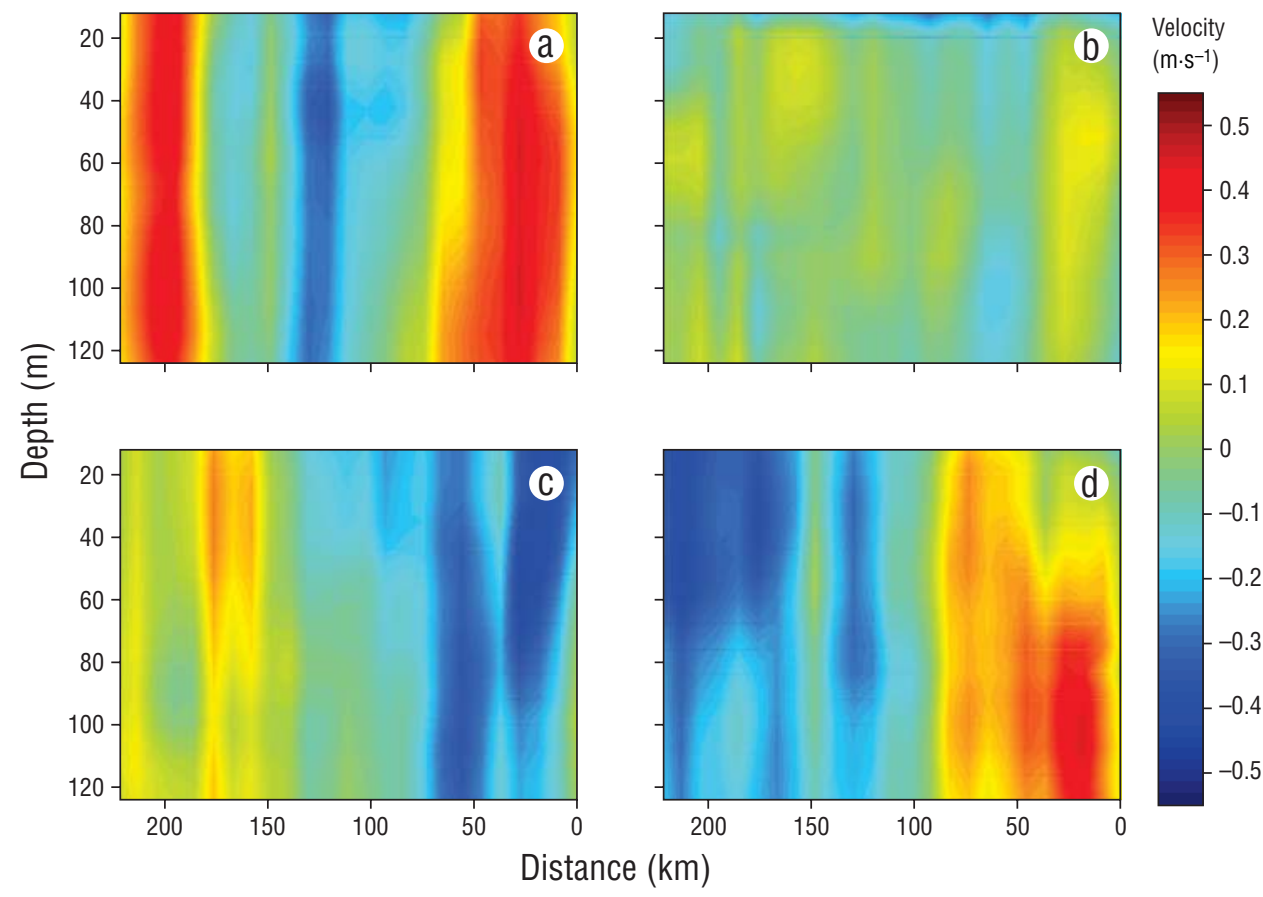

Figure 4. Vertical cross section of alongshore current velocity off Ensenada, Baja California (Mexico), during the October 2001 (a), January 2002 (b), April 2002 (c), and July 2002 (d) surveys. Positive values mean poleward flows.

Figura 4. Corte transversal vertical de la velocidad de la corriente a lo largo de la costa frente a Ensenada, Baja California (México), durante los muestreos de octubre de 2001 (a), enero de 2002 (b), abril de 2002 (c) y julio de 2002 (d). Los valores positivos representan flujos hacia el polo.

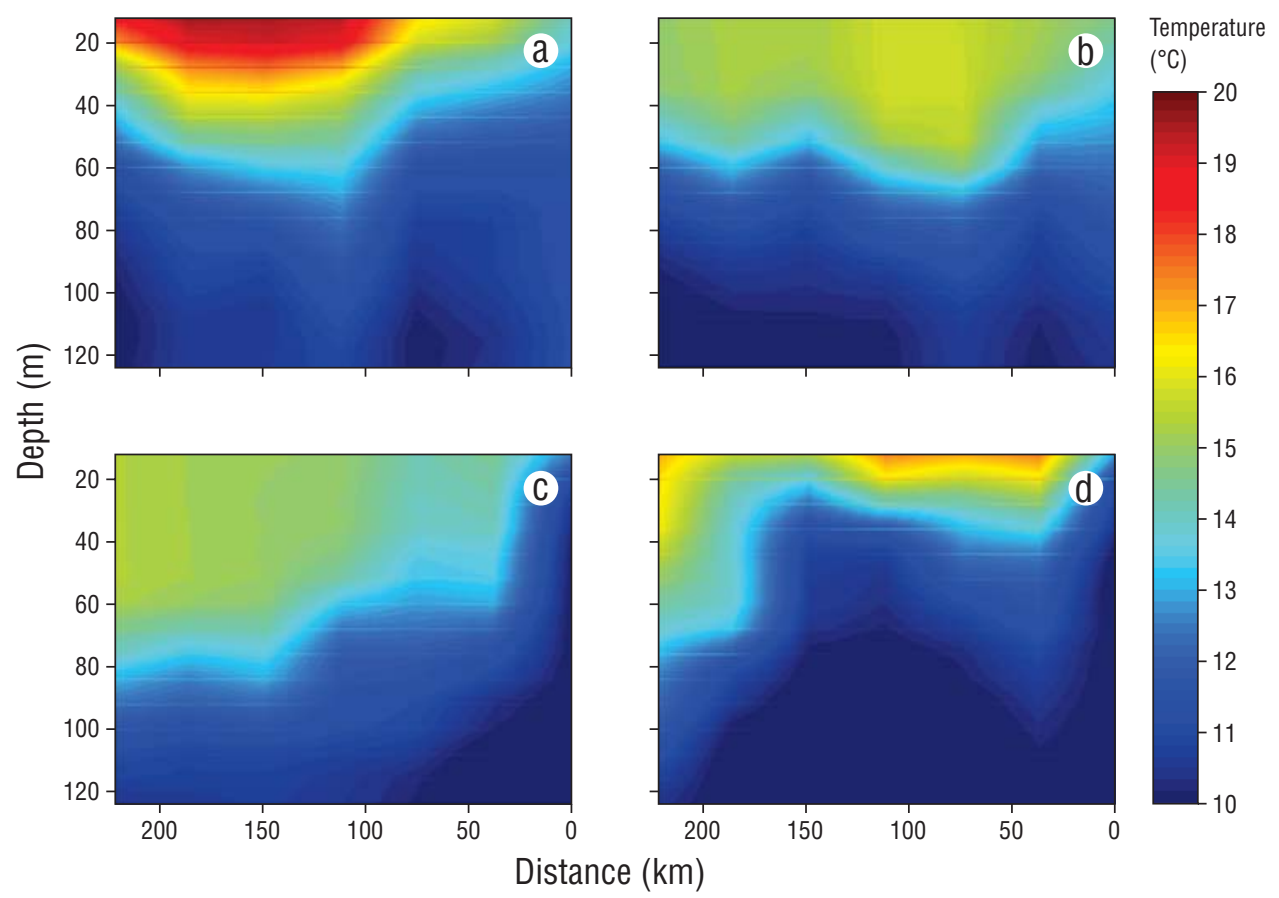

Figure 5. Vertical cross section of temperature off Ensenada, Baja California (Mexico), during the October 2001 (a), January 2002 (b), April 2002 (c), and July 2002 (d) surveys.

Figura 5. Corte transversal vertical de la temperatura a lo largo de la costa frente a Ensenada, Baja California (México), durante los muestreos de octubre de 2001 (a), enero de 2002 (b), abril de 2002 (c) y julio de 2002 (d). 
upwelling-favorable and relaxation wind events. We calculated total kinetic energy over the wind field for each 6-hourly dataset in the area of interest considering constant air density, and we found a high correlation (0.8) between the temporal series of kinetic energy and the first PC of the wind stress curl, which means that the positive phase of the wind stress curl is associated with strong winds and the negative phase is associated with less intense winds and, in some cases, wind relaxations. This is relevant because wind relaxation events in the area are related to the wind stress curl, which is thought to be important in the dynamics of the region (e.g., Enriquez and Friehe 1995; Wang 1997). Although the average wind stress field is predominantly parallel to the coast (upwelling favorable), the presence of relaxations is quite common in the study area (Vazquez 2011). The method proposed is robust and can easily pinpoint wind relaxations.

Using vessel-mounted ADCP and CTD observations, surface circulation associated with wind events in the northern Baja California upwelling region was documented for the period between October 2001 and July 2002. Two circulation patterns were clearly defined: (1) the relaxation pattern, which consists of a coastal warm poleward flow and a cyclonic eddy clearly observed during the October 2001 and July 2002 cruises, with wind relaxation occurring at the beginning of both cruises; and (2) the upwelling pattern, which consists of an equatorward coastal jet and an offshore poleward flow confined to the surface during the April 2002 cruise. Similar patterns have been observed along the coast of California and Oregon. Harms and Winant (1998) found that cyclonic circulation and poleward flow occur concurrently in the Santa Barbara Channel. On the other hand, the observations in our study area for January are quite particular. A large positive wind stress curl occurred at the beginning of the survey, which was associated with the presence of a cold front. The strong equatorward winds thus induced an equatorward flow. However, a wind relaxation event occurred before the start of the survey. From satellite altimetry (not shown) we found that a poleward flow was taking place along the coast on those days, but the IMECOCAL data kept only a fainted poleward flow. Our hypothesis is that the cold front (strong winds) inhibited the relaxation pattern, hence the poleward flow.

Wang (1997) suggested that coastal poleward flows are driven by an alongshore pressure gradient that is generated by a cyclonic eddy. Our observations are in agreement with this author's hypothesis; his numerical experiment on relaxation shows a good comparison with the relaxation pattern. On the other hand, Oey (1999) hypothesized that the forcing mechanism generating coastal poleward flows is the equatorward weakening of the wind stress curl. Our alongshore scale $(\sim 400 \mathrm{~km})$, however, is too small to test this hypothesis. Pringle and Dever (2009) suggested that changes in the intensity of coastal upwelling along the coast drive poleward flows.

The results we obtained are promising and help better understand the coastal dynamics off the northern Baja California el método es insensible a la elección del conjunto de datos. Sobresale la relación entre los eventos de relajación y la primer CP del rotacional del esfuerzo del viento; encontramos que la variabilidad del rotacional del esfuerzo del viento está controlada por eventos de vientos favorables para las surgencias y eventos de relajación. Calculamos la energía cinética total sobre el campo del viento para cada conjunto de datos de $6 \mathrm{~h}$ considerando una densidad constante del aire, y encontramos una alta correlación (0.8) entre la serie temporal de energía cinética y la serie temporal del primer modo de la $\mathrm{CP}$ para el rotacional del esfuerzo del viento, lo que significa que la fase positiva del rotacional del esfuerzo del viento está relacionada con vientos fuertes y la fase negativa está relacionada con vientos débiles y, en ocasiones, con eventos de relajación del viento. Esto es relevante debido a que los eventos de relajación del viento están relacionados con el rotacional del esfuerzo del viento, que se piensa es importante para la dinámica de la región (e.g., Enriquez y Friehe 1995; Wang 1997). Aunque el campo medio del esfuerzo del viento es predominantemente paralelo a la costa (favorable para las surgencias), la presencia de los eventos de relajación es bastante común en la región de estudio (Vazquez 2011). El método aquí propuesto es robusto y puede identificar eventos de relajación fácilmente.

Se documentó la circulación asociada a eventos de viento en el periodo entre octubre de 2001 y julio de 2002 mediante observaciones de ADCP y CTD tomadas en barco en la zona de surgencias frente a la región norte de la península de Baja California. Se identificaron 2 patrones de circulación: (1) el patrón de relajación, el cual consiste en la presencia de un flujo costero de agua cálida con dirección hacia el polo y un remolino ciclónico durante los cruceros de octubre de 2001 y julio de 2002, en ambos casos con un evento de relajación al inicio del crucero; y (2) el patrón de surgencias, el cual consiste en un chorro costero hacia el ecuador y un flujo fuera de la costa con dirección hacia el polo y confinado en la superficie, ambos observados durante el crucero de abril de 2002. Se han observado patrones similares a lo largo de la costa de California y Oregón. Harms y Winant (1998) encontraron que en el canal de Santa Bárbara la circulación ciclónica y los flujos hacia el polo ocurren de manera simultánea. Por otra parte, las observaciones en enero son algo particulares. Un rotacional del esfuerzo del viento grande y positivo ocurrió al inicio del crucero, el cual se relacionó con la presencia de un frente frío. Los vientos intensos hacia el ecuador, por tanto, indujeron un flujo hacia el ecuador. Sin embargo, antes del inicio del crucero ocurrió un evento de relajación. Con base en datos de altimetría satelital (no mostrados), encontramos que hubo un flujo hacia el polo a lo largo de la costa durante esos días, pero los datos de IMECOCAL retuvieron únicamente un flujo débil hacia el polo. Nuestra hipótesis es que el frente frío (vientos intensos) inhibió el patrón de relajación y, por ende, el flujo hacia el polo.

Wang (1997) propuso que los flujos costeros hacia el polo son causados por un gradiente de presión a lo largo de la costa 
coast, highlighting the necessity for analyzing the dynamics of not only upwelling events but also wind relaxation events. Our contribution demonstrated the value of the IMECOCAL database, capturing the dynamics associated with different wind scenarios. A future work will characterize wind events off southern Baja California and study the response of the ocean.

\section{ACKNOWLEDGMents}

This work has been supported, in part, by grants 82529 , 23947, 23804, and 257125 from the National Council for Science and Technology (CONACYT, Mexico). HJV was granted a fellowship by CONACYT. Support was received from the Office of Naval Research as part of the Flow Encountering Abrupt Topography (FLEAT) project award (N00014-15-1-2285). HJV thanks Bruce Cornuelle for his support and insightful comments. Suggestions and comments of the anonymous reviewers are gratefully acknowledged. We also thank the captain and crew of the R/V Francisco de Ulloa from CICESE.

\section{REFERENCES}

Bakun A, Nelson CS. 1991. The seasonal cycle of wind-stress curl in subtropical eastern boundary regions. J. Phys. Oceanogr. 21: 1815-1834. https://doi.org/10.1175/1520-0485(1991)021<1815:tscows $>2.0$. co;2

Bendat JS, Piersol AG. 2010. Random Data: Analysis and Measurement Procedures. Wiley (NJ), $604 \mathrm{pp}$.

Durazo R. 2015. Seasonality of the transitional region of the California Current System off Baja California. J. Geophys. Res. 120(2): 1173-1196. http://dx.doi.org/10.1002/2014JC010405

Emery WJ, Thomson RE. 1998. Data Analysis Methods in Physical Oceanography. Pergamon, New York, 634 pp.

Enriquez AG, Friehe CA. 1995. Effects of wind stress and wind stress curl variability on coastal upwelling. J. Phys. Oceanogr. 25(7): 1651-1671.

https://doi.org/10.1175/1520-0485(1995)025<1651:eowsaw>2.0. co;2

Garel E, Laiz I, Drago T, Relvas P. 2016. Characterisation of coastal counter-currents on the inner shelf of the Gulf of Cadiz. J. Mar. Syst. 155: 19-34. http://dx.doi.org/10.1016/j.jmarsys.2015.11.001

Gay PS, Chereskin TK. 2009. Mean structure and seasonal variability of the poleward undercurrent off southern California. J. Geophys. Res. 114(C2): C02007. http://dx.doi.org/10.1029/2008JC004886

Gomez-Valdes J, Jeronimo G. 2009. Upper mixed layer temperature and salinity variability in the tropical boundary of the California Current, 1997-2007. J. Geophys. Res. 114(C3): C03012. http://dx.doi.org/10.1029/2008JC004793

Harms S, Winant CD. 1998. Characteristic patterns of the circulation in the Santa Barbara Channel. J. Geophys. Res. 103(C2): 3041-3065. https://doi.org/10.1029/97jc02393

Hickey BM. 1979. The California current system-Hypotheses and facts. Prog. Oceanogr. 8(4): 191-279. https://doi.org/10.1016/0079-6611(79)90002-8 que es generado por un remolino ciclónico. Nuestras observaciones concuerdan con su hipótesis; su experimento numérico con relajaciones muestra una buena comparación con el patrón de relajación. Por otra parte, Oey (1999) sugiere que el mecanismo forzador para generar flujos costeros hacia el polo es el debilitamiento hacia el ecuador del rotacional del esfuerzo del viento. Sin embargo, nuestra escala espacial a lo largo de la costa $(\sim 400 \mathrm{~km})$ es muy pequeña para probar esta hipótesis. Pringle y Dever (2009) proponen que los cambios en la intensidad de la surgencia costera a lo largo de la costa generan flujos hacia el polo.

Los resultados obtenidos son prometedores y ayudan a entender de mejor manera la dinámica costera en las aguas frente a la costa norte de Baja California, resaltando la necesidad de analizar no únicamente los eventos de surgencias, sino también los eventos de relajación del viento. Nuestra contribución demuestra el valor del conjunto de datos tomado por el programa IMECOCAL, el cual captura la dinámica asociada a diferentes escenarios de viento. Un trabajo futuro será caracterizar los eventos de viento frente a la parte sur de la península de Baja California y estudiar la respuesta del océano.

\section{Agradecimientos}

Este trabajo fue parcialmente financiado por el Consejo Nacional de Ciencias y Tecnología (CONACYT, México) a través de las becas 82529, 23947, 23804 y 257125 . HJV recibió una beca del CONACYT. Se recibió apoyo de la Oficina de Investigación Naval como parte del proyecto Flow Encountering Abrupt Topography (FLEAT, proyecto no. N00014-15-1-2285). HJV agradece el apoyo y las valiosas observaciones de Bruce Cornuelle. Se agradecen las sugerencias y los comentarios de los revisores anónimos. Nuestro agradecimiento también es para el capitán y la tripulación del B/I Francisco de Ulloa del CICESE.

Hill AE, Hickey BM, Shillington FA, Strub PT, Brink KH, Barton ED, Thomas AC. 1998. Eastern Ocean Boundaries. In: Robinson AR, Brink KH (eds.), The Sea-The Global Coastal Ocean Regional Studies and Synthesis. John Wiley, Hoboken (NJ), pp. 29-68.

Jerónimo G, Gómez-Valdés J. 2007. A subsurface warm-eddy off northern Baja California in July 2004. Geophys. Res. Lett. 34(6): L06610. http://dx.doi.org/10.1029/2006GL028851

Kundu PK. 1976. Ekman veering observed near the ocean bottom. J. Phys. Oceanogr. 6(2): 238-242. https://doi.org/10.1175/1520-0485(1976)006<0238:EVONTO $>2$ .0. $\mathrm{CO} ; 2$

Lynn RJ, Simpson JJ. 1987. The California Current System: The seasonal variability of its physical characteristics. J. Geophys. Res. 92(C2): 12947-12966.

Melton C, Washburn L, Gotschalk C. 2009. Wind relaxation and poleward events in a coastal upwelling system on the central California coast. J. Geophys. Res. 114(C11): C11016. http://dx.doi.org/10.1029/2009JC005397 
Oey L-Y. 1999. A forcing mechanism for the poleward flow off the southern California coast. J. Geophys. Res. 104(C6): 13529-13539. https://doi.org/10.1029/1999jc900066

Philander SGH, Yoon J-H. 1982. Eastern boundary currents and coastal upwelling. J. Phys. Oceanogr. 12(8): 862-879. https://doi.org/10.1175/1520-0485(1982)012<0862:ebcacu >2.0.co;2

Pringle JM, Dever EP. 2009. Dynamics of wind-driven upwelling and relaxation between Monterrey Bay and Point Arena: Local-, regional-, and gyre-scale controls. J. Geophys. Res. 114(C07): C07003. http://dx.doi.org/10.1029/2008JC005016

Relvas P, Barton ED. 2002. Mesoscale patterns in the Cape São Vicente (Iberian Peninsula) upwelling region. J. Geophys. Res. 107(C10): 3164. http://dx.doi.org/10.1029/2000JC000456

Rossby T, Flagg C, Ortner P, Hu C. 2011. A tale of two eddies: Diagnosing coherent eddies through acoustic remote sensing. J. Geophys. Res. 116(C12): C12017. http://dx.doi.org/10.1029/2011JC007307

Soto-Mardones L, Parés-Sierra A, Garcia J, Durazo R, Hormazabal S. 2004. Analysis of the mesoscale structure in the IMECOCAL region (off Baja California) from hydrographic, ADCP and altimetry data. Deep Sea Res., Part II 51(6-9): 785-798. http://dx.doi.org/10.1016/j.dsr2.2004.05.024
Torres HS, Gomez-Valdes J. 2015. Coastal circulation driven by short-period upwelling-favorable winds in the northern Baja California region. Deep Sea Res., Part I 98: 31-42. https://doi.org/10.1016/j.dsr.2014.12.003

Vazquez HJ. 2011. Patrones de circulación superficial frente a Baja California. Dissertartion, Centro de Investigación Científica y de Educación Superior de Ensenada, Ensenada, Baja California, Mexico.

Vazquez HJ, Gomez-Valdes J, Ortiz M, Dworak JA. 2011. Detiding shipboard ADCP data in Eastern Boundary Current. J. Atmos. Oceanic Tech. 28(1): 94-103. http://dx.doi.org/10.1175/2010JTECHO697.1

Wang D-P. 1997. Effects of small-scale wind on coastal upwelling with application to Point Conception. J. Geophys. Res. 102 (C7): 15555-15566. http://dx.doi.org/10.1029/97JC00635

Winant CD, Dever EP, Hendershott MC. 2003. Characteristic patterns of shelf circulation at the boundary between central and southern California. J. Geophys. Res. 108(C2): 3021. http://dx.doi.org/10.1029/2001JC001302

Winant CD, Dorman CE. 1997. Seasonal patterns of surface wind stress and heat flux over the Southern California Bight. J. Geophys. Res. 102(C3): 5641-5653. https://doi.org/10.1029/96jc02801

Received March 2017,

accepted June 2017. 